$12-31-2019$

\title{
Patient safety smartphone application for quality Assurance in primary healthcare facilities
}

\author{
Levina Chandra Khoe \\ Department of Community Medicine, Faculty of Medicine, Universitas Indonesia, Indonesia, \\ levinachandramd@gmail.com \\ Ajeng Pramastuty \\ Universitas Indonesia, Indonesia, apramastuty@gmail.com
}

See next page for additional authors

Follow this and additional works at: https://scholarhub.ui.ac.id/ajce

Part of the Medicine and Health Sciences Commons

\section{Recommended Citation}

Khoe, Levina Chandra; Pramastuty, Ajeng; Sabarguna, Boy Subirosa; and Herqutanto, Herquranto (2019). Patient safety smartphone application for quality Assurance in primary healthcare facilities. ASEAN Journal of Community Engagement, 3(2).

Available at: https://doi.org/10.7454/ajce.v3i2.1064

Creative Commons License

(c) (i) ()

This work is licensed under a Creative Commons Attribution-Share Alike 4.0 License.

This Case-Based Article is brought to you for free and open access by the Universitas Indonesia at ASEAN Journal of Community Engagement. It has been accepted for inclusion in ASEAN Journal of Community Engagement. 


\title{
Patient safety smartphone application for quality Assurance in primary healthcare facilities
}

\author{
Levina Chandra Khoe ${ }^{a^{*}}$, Ajeng Pramastutyb, Boy Subirosa Sabarguna, \\ Herqutanto ${ }^{\mathrm{a}}$
}

\author{
a Department of Community Medicine, Faculty of Medicine, Universitas Indonesia, Indonesia \\ ${ }^{b}$ Faculty of Engineering, Universitas Indonesia, Indonesia
}

Received: December $6^{\text {th }}, 2018 \|$ Revised: December $1^{\text {st }}, 10^{\text {th }} \& 17^{\text {th }}, 2019 \|$ Accepted: December $30^{\text {th }}, 2019$

\begin{abstract}
In order to achieve high-quality healthcare, patient safety should be improved and monitored regularly. Moreover, accreditation on healthcare facilities is being requested in recent years. Mobile application can serve as a tool for community healthcare centre's (Puskesmas) to assess their accreditation score, especially patient safety. To provide as a tool for self-monitoring for patient safety elements. This is a case-based article focuses on the development of smartphone application using the input-process-output-outcome scheme as the framework. We reviewed regulation of health minister on Puskesmas accreditation and developed a checklist and scoring for patient safety components. This is the first mobile application that targeted Puskesmas staff to improve their quality of care in patient safety based on accreditation criteria. The application is publicly available in Google Play Store. We promoted the application among Puskesmas staff and asked for their evaluation using Google Form. About 20 Puskesmas responded and showed positive response. This smartphone application serves as self-monitoring tool for Puskesmas to complete accreditation criteria as mentioned in Permenkes No 46 Year 2015. We would promote the use of this application to wider Puskesmas community.
\end{abstract}

Keywords: patient safety, Puskesmas, accreditation, mobile application, smartphone application

\section{Introduction}

With the implementation of national health insurance (JKN) in Indonesia, the number of patients in the primary healthcare facilities increased tremendously. Data from the Healthcare and Social Security Agency (BPJS) showed more than 80\% increase in outpatient service in primary healthcare facilities from 66.8 million to 120.9 million JKN participants (BPJS Kesehatan, 2017). The high load of patients should be directly proportional to the service quality's improvement. Ekawati, et al. (2017) interviewed twenty-three patients about their experience of using primary care service in the era of JKN. She found that the majority of patients were in doubt with the quality of general practice (GP). Eventually, it would affect patient's trust on primary care system. Besides 
Levina Chandra Khoe, Ajeng Pramastuty, Boy Subirosa Sabarguna, Herqutanto | ASEAN Journal of Community Engagement | Volume 3, Number 2, 2019

that, difficulty in accessing primary care and low quality of care had also been reported (Santosa \& Malek, 2011 \& Putri, 2014).

Accreditation is one of the approaches used to maintain the quality of care. Hospital accreditation has widely been implemented internationally and locally to improve their performance. However, accreditation in primary care is still limited (Paccioni, Sicotte, \& Champagne, 2008). Buetow \& Wellingham (2003) discussed how accreditation of general practice can be used for quality control and improvement. Another study by Braun et al (2008) also found that accredited primary care centers were more committed to improve their service quality compared to non-accredited facilities. Accreditation in all type of health services, primary, secondary, and also tertiary care, should be done.

Primary care in Indonesia is mainly run by public primary health facilities or so called Puskesmas and a small number of private clinics. In 2018, there were 9,993 Puskesmas scattered over 34 provinces, with $36 \%$ of them located in Java Islands. Among this number, 24,36\% were lack of doctors and 45,53\% lack of dentists (Ministry of Health, 2018). By merely observing this data, we could imagine the service quality provided by underqualified human resources and its impact to population health. Data from the Ministry of Health (2017) also revealed 43.84\% Puskesmas in Indonesia had been accredited. However, most of them were in basic (dasar) or intermediate (madya) accredited.

Primary healthcare provided by Puskesmas is the first-line health services that can be reached by general population. Since 2015, Puskesmas are ought to be accredited. In 2015, there were only $26.6 \%$ districts that had at least one accredited Puskesmas. However, in 2016, there were huge improvement, 1,308 districts had at least one accredited Puskesmas. This number exceeded the expected target of 700 districts. Similar phenomenon was happened in 2017, when more districts had accredited Puskesmas. (Ministry of Health, 2017). This was quite a breakthrough, even though, the accreditation status was still mostly in basic and intermediate.

The Minister established Regulation of Minister of Health No 46 Year 2015 which contains number of standards related with healthcare provision in primary healthcare facilities. Besides due to quality reason, one of the main objectives of accreditation is to provide a safe procedure and health service for patients. Quality and safety are closely intertwined, as patient safety could only be achieved through optimal healthcare quality (WHO, 2003; Darzi, 2008). The concept of patient safety was born in 1999, where report 
Levina Chandra Khoe, Ajeng Pramastuty, Boy Subirosa Sabarguna, Herqutanto | ASEAN Journal of Community Engagement | Volume 3, Number 2, 2019

from Institute of Medicine published a high number of mortality due to medical error in the United States. Since the publication, there is an increasing concern on patient safety among medical professionals (Institute of Medicine US Committee on Quality of Health Care in America, 2000). World Health Organization (WHO, 2017) defines patient safety as "the absence of preventable harm to a patient and reduction of risk of unnecessary harm associated with healthcare to an acceptable minimum". Every medical procedure has a certain amount of risk to fall into medical error. By implementing patient safety, we aim to reduce the risk into an acceptable threshold, and eventually avoid medical errors.

Considering the importance of patient safety, the Minister of Health includes this in one specific chapter in the accreditation criteria. Accreditation is positively associated with better patient safety system (Shaw et al., 2014). Therefore, an accredited health facility with full mark ("paripurna") would provide a good patient safety system. In accreditation standards, every activity must be recorded and documented. Without documentation, the assessor would not be able to measure the healthcare organizations' performance (Jaafaripooyan, Agrizzi, \& Akbari-Haghighi 2011). However, accreditation requires complex procedure and many administrative issues (Kapur, 2015). Problem appears since people are not used to document all their activities (El-Jardali et al., 2014). Therefore, when the time is coming for accreditation, people are busy to prepare documents and have less time for routine healthcare service. In order to avoid the complexity of administration process, we are developing a mobile application that is useful for self-assessment and keeping the track of all necessary documents.

In the era of technology development, the use of mobile applications is gaining more attention. In Indonesia alone, about 53.86 million or $20.93 \%$ people used mobile phone in 2016. It is also predicted that the number of users would greatly increase about 1.6 times more in 2022 (Statista, 2019). This also applied in medical community, where various mobile health applications are blooming across different countries (Qiang, Yamamichi, Hausman, \& Altman 2011; Boulos et al., 2014; Lu et al., 2018). Most healthcare professionals used medical application for information management, communication and consulting, reference and information gathering, patient management and monitoring, medical education and training (Ozdalga, Ozdalga, \& Ahuja, 2012; Lewis \& Wyatt, 2014; Ventola, 2014). While the use of mobile application for healthcare accreditation is still uncommon, mobile application as an audit checklist application have been developed for ISO 9001 to help prepare the audit process. Using the same concept of audit checklist tool, 
Levina Chandra Khoe, Ajeng Pramastuty, Boy Subirosa Sabarguna, Herqutanto | ASEAN Journal of Community Engagement | Volume 3, Number 2, 2019

we planned to develop a mobile application that help accreditation process, especially regarding patient safety system in Puskesmas.

In Indonesia, this type of application does not exist yet for healthcare management. The available applications are typically targeted business markets, managers, auditors, but limited attention in the world of healthcare management, especially primary level. With government regulation for accreditation in the primary healthcare, there is no doubt that healthcare managers need a help tool to manage documents and matched them with it chapter in accreditation regulation.

\section{Methods}

\subsection{Study design}

This is a case-based paper that focused on the development of mobile health application for healthcare managers at primary level. Input-process-output (IPO) model is used as framework to design the application. It is commonly used in system analysis and software development to describe the information processing program. By using this model, we were able to identify the input and evaluate the process and output. We used the framework of input-process-output-outcome, as follow:

Input : patient safety accreditation form in Puskesmas

Process : software development

Output : mobile health application and decision support system

Outcome : Puskesmas fulfilled accreditation criteria for patient safety

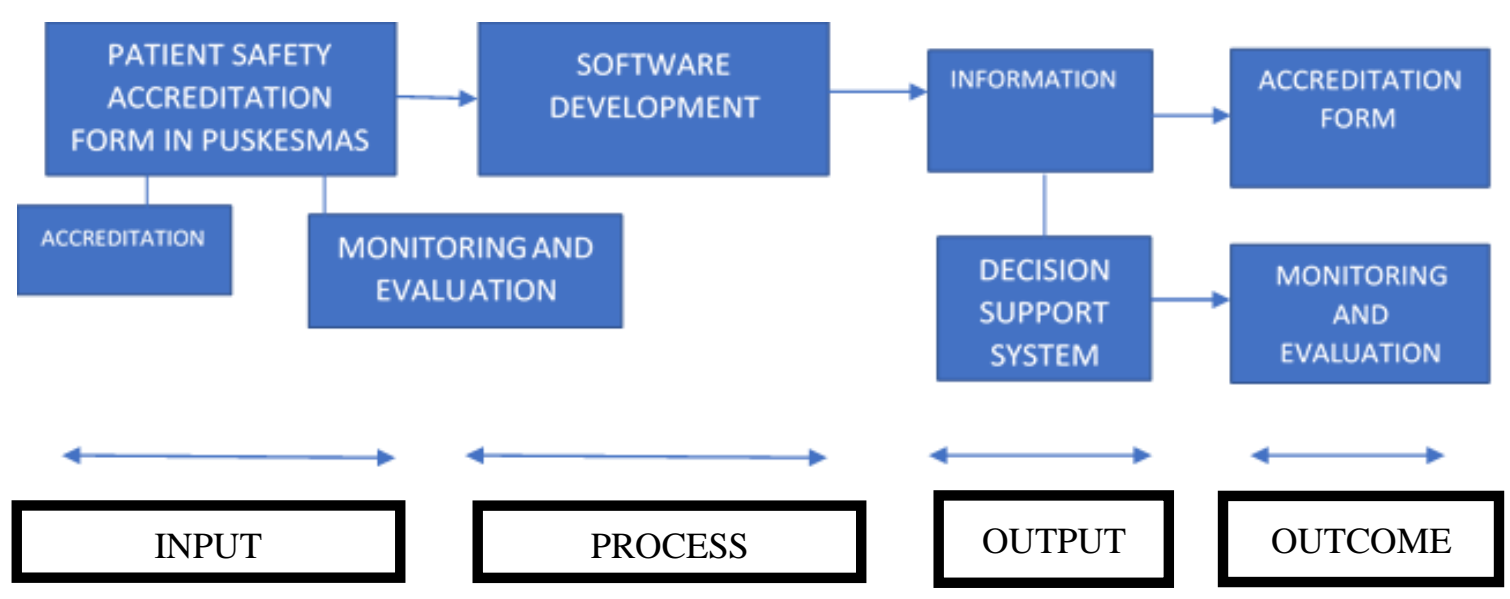

Fg. 1 Diagram Process of Workflow

Source: Author (2018) 
Levina Chandra Khoe, Ajeng Pramastuty, Boy Subirosa Sabarguna, Herqutanto | ASEAN Journal of Community Engagement | Volume 3, Number 2, 2019

In the input, we collected information from primary and secondary sources. Primary sources were obtained from in-depth interview with staff from the Ministry of Health and Health Subdistrict Office. In the Ministry of Health, we had discussion with the staff from Directorate of Quality and Accreditation of Primary Health Care. In addition, we also talked with the staff from Health Service in one of the Health Subdistrict Office in Jakarta. The questions included information about the accreditation process, accreditation form, and monitoring process by Health Subdistrict Office.

While secondary sources were gained from review of literatures and existing policies related to accreditation in primary healthcare. All information was used to understand patient safety accreditation form in Puskesmas, which would be the basis for software development. During the process, we discussed with the application developer and tested the application among programmers. The output was the functional mobile application which has decision support system. The system would provide the score for users depending on the completeness of documents, and it would also give recommendation or input if they do not reach maximum score (580). Eventually, as the outcome, this mobile application aims to help Puskesmas in achieving accreditation criteria for patient safety component.

\subsection{Duration of research}

It took ten months to develop and finalize the mobile application. During this period, about six months are necessary for preparation and software development. While the rest four months are used for trial, promotion, and evaluation.

\subsection{Accreditation form}

The accreditation form consists of patient safety' indicators as described in Chapter 9 in the Regulation of Minister of Health No 46 Year 2015. There were 4 sub-chapters with total of 58 indicators. In each indicator, there were internal and/or external documents to fulfill the criteria.

\subsection{Software development}

Result from content development was transferred to application development team to build the software. The framework used for content development was derived from 
Levina Chandra Khoe, Ajeng Pramastuty, Boy Subirosa Sabarguna, Herqutanto | ASEAN Journal of Community Engagement | Volume 3, Number 2, 2019

Chapter 9 in the Regulation of Minister of Health No 46 Year 2015. The application design base is divided into two parts: 1) introduction, and 2) content.

In the introduction, the user can start by login or register their email and identity. The user should register his/her institution, in this case Puskesmas/clinic. Before entering the application, user would find disclaimer which stated the adoption of this application from Chapter 9 in the Regulation of Minister of Health No 46 Year 2015. In the front page, user could find email address of the developer team for discussion and ask questions to the developer. Video tutorial and manual book are also provided here.

In the content, there are 58 indicators as described in the regulation. User could select one indicator and user could enter the assessment page of the indicator. In the assessment page, there will be an explanation about the indicator. We included all indicators mentioned in the sub-chapter and its components. In each indicator, there is requirement to fulfill certain documents. Additional function for uploading documents were embedded in this application. User could upload the required documents from computer to the smartphone by scanning QR code in the application. If all the necessary documents were uploaded, then there will be a green sign in the indicator. If the requirements were not yet completed, the red cross sign appears.

After fulfilling all the required documents in all indicators, user could click on the right top of the indicator page. It will show the score rating. Zero is score given when there is no one document uploaded, five is score given when only partial document uploaded. Meanwhile 10 score given when document uploaded is match with the requirement. If all criteria were fulfilled, then user would obtain a full mark of 580. Result score in this application will become baseline of decision support system. Decision support system will give user recommendation and suggestion about things that should be corrected.

\subsection{Evaluation of mobile application}

We did evaluation of this application by testing it to IT team and the end user. The IT team would test the functionality of the application. The IT team here were programmer who had experienced in developing smartphone application. We selected the programmers consecutively. We asked the IT team for their input regarding the function, the system flow and appearance of the application. Questionnaire based Likert scale was used to measure their assessment. 
Levina Chandra Khoe, Ajeng Pramastuty, Boy Subirosa Sabarguna, Herqutanto | ASEAN Journal of Community Engagement | Volume 3, Number 2, 2019

While the end users here were Puskesmas staff who in charge of patient safety system in their facility. One staff per Puskesmas was asked to fill in the questionnaire. We used a set of questionnaires and assessed them using Likert scale to measure their expectation and satisfaction level.

\subsection{Study subjects}

For testing among IT person, we selected four IT persons consecutively. We gave them a link for downloading the application, also sent the informed consent and questions by email.

While for the end user, we held a socialization event to promote this application. We sent invitation to the Health District Office, which they would distribute to all Puskesmas in Jakarta, including District and Subdistrict Puskesmas. We asked a representative of each Puskesmas, primarily those who work on building patient safety strategy in Puskesmas. There are 42 district Puskesmas in Jakarta (excluding Kepulauan Seribu) and 331 subdistrict Puskesmas (DKI Jakarta local government, n. d.). Since this was a pilot project, we limited the quota for 30 Puskesmas, and would expand later after we received some feedback from the end-users.

\subsection{Location}

The evaluation for end users took place at the Department of Community Medicine, Faculty of Medicine, Universitas Indonesia, on December 2018. While for IT persons, the evaluation was done independently and the result were acquired through email.

\section{Result and Discussion}

\subsection{Interview with stakeholders}

We did interviews with staff from the Directorate of Quality and Accreditation of Primary Health Care, Minister of Health, and Health Subdistrict Office. Information about application and the purpose of this application were explained to respondents. We asked their opinion about the use, challenges, and recommendation for the mobile application development (See Table 1). 
Levina Chandra Khoe, Ajeng Pramastuty, Boy Subirosa Sabarguna, Herqutanto | ASEAN Journal of Community Engagement | Volume 3, Number 2, 2019

Table 1. Use, Challenges, and Recommendation for Mobile Application Development

\section{Minister of Health Health Subdistrict Office}

\begin{tabular}{ll}
\hline Use of application & This application would be It is useful for Puskesmas staff \\
& helpful for Puskesmas to to collect all necessary \\
& monitor their own progress documents for accreditation \\
Challenge & It should be emphasized that The application would need \\
& accreditation is not merely internet connection, while there \\
& about completing all were doubts whether it would \\
& documents, but the process / be available in all Puskesmas \\
& daily activities should be taking \\
& into consideration
\end{tabular}

Recommendation The idea to present scoring In the long run, the team should system is good and should be develop the application to cover followed up with all chapters in accreditation suggestion/recommendation to Puskesmas.

There should be a disclaimer in the application that this application only included Chapter 9, not all Chapters

Source: Author (2018)

\subsection{Literature review}

We reviewed the Regulation of Minister of Health No 46 Year 2015 about accreditation in primary healthcare and the Regulation of Minister of Health No 11 Year 2017 about patient safety. In Puskesmas accreditation criteria, there are three main groups: 1) administration and management; 2) public health; and 3) personal health service. Patient safety is under the group of personal health service, along with patient-oriented clinical service and supportive management for clinical service. Puskesmas and private clinics would be re-assessed for accreditation every three years. Throughout the accreditation process, Puskesmas will be monitored by Subdistrict Health Office. Assessment for 
Levina Chandra Khoe, Ajeng Pramastuty, Boy Subirosa Sabarguna, Herqutanto | ASEAN Journal of Community Engagement | Volume 3, Number 2, 2019

accreditation will be done by surveyor team, whom will be selected by the Ministry of Health. There are five type of accreditation status: 1) unaccredited; 2) basic accredited (terakreditasi dasar); 3) intermediate accredited (terakreditasi madya); 4) major accredited (terakreditasi utama); and 5) complete accredited (terakreditasi paripurna). This is applied for Puskesmas, and not for clinics. For private clinics, they merely have four type of accreditation status, not including major accredited.

In chapter 9 on patient safety, there are four standards, covering 1) human resources; 2) function and process; 3) measurement and assessment; and 4) evaluation and communication. In each standard, there are elements for assessment. These elements are used for assessment indicators. In total, we identified 58 indicators in Chapter 9. In each indicator, there will be a requirement for internal or external documents to fulfill the indicator. These indicators were used as basis for application framework.

The Regulation of Minister of Health No 11 Year 2017 specifically focuses on patient safety in all type of health facilities, including hospitals, Puskesmas, and clinics. Every health facility should have a special committee for patient safety. The standards for patient safety include patient's right, education for patient and family, patient safety in health service, methods in improving evaluation and patient safety, leadership role, education for staff, and communication. Any incidents related to patient safety should be reported to internal committee in the health facility, and also externally to national committee of patient safety through website and email. However, the website could not be opened, and the facility code, until this study was accomplished, is available only for hospitals.

We also searched literatures about patient safety in primary healthcare and found two systematic reviews. Lawati, Dennis, Short, \& Abdulhadi (2018) reviewed 28 papers and found that safety culture of an organization is the first step to build the patient safety system. Additionally, blame culture still exists among health professionals. This culture could hinder staff from reporting patient safety incidents. Openness in communication should be encouraged and accustomed in daily activities. Another study by Marchon \& Mendes (2014) also found that communication either among healthcare staff or between staff and patients is important to improve patient safety. Moreover, the review stressed the need to empower healthcare staff in implementing patient safety strategies. 
Levina Chandra Khoe, Ajeng Pramastuty, Boy Subirosa Sabarguna, Herqutanto | ASEAN Journal of Community Engagement | Volume 3, Number 2, 2019

\subsection{Mobile Health Application}

The mobile health application is entitled "Aplikasi Keselamatan Pasien di Puskesmas (AKPP)" or patient safety application in Puskesmas. Users could easily find this application in Google Play Store. They can download this application directly. The language used in this application is Indonesian language because it is targeted to Puskesmas staff.
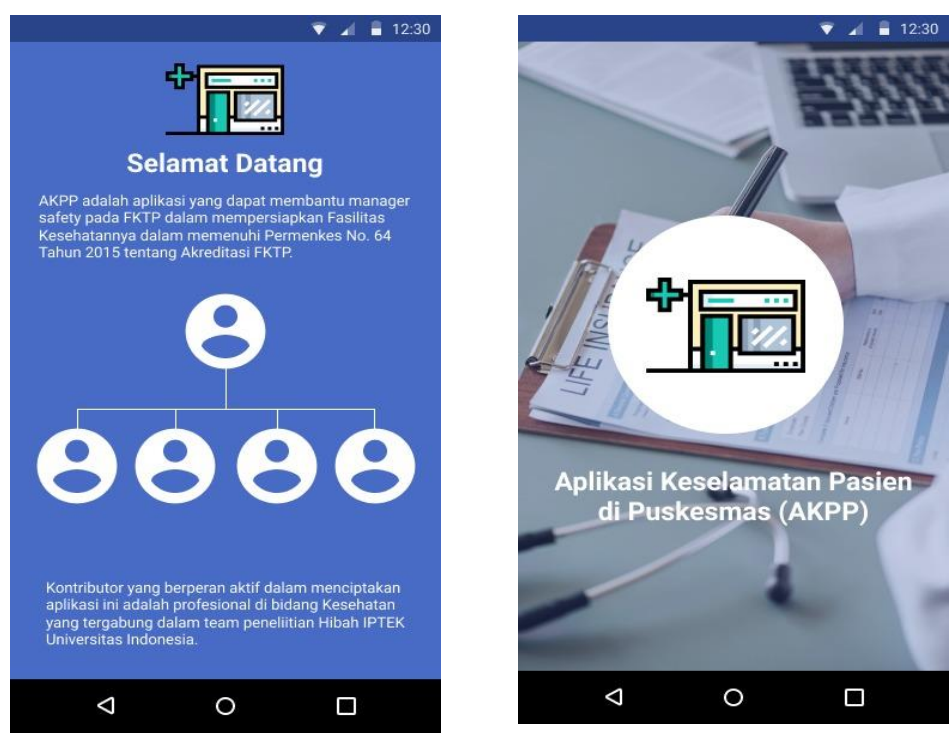

Fg. 2 Front Display of AKPP

Source: Author (2018)

When the user opened the application, he/she would find the welcoming remark and the team structure. After swiping the display, they would continue to disclaimer and manual page. In this page, there is a disclaimer that this application contents are referring to chapter 9 of Regulation of Minister of Health No 46 Year 2015, and not included other chapters in the accreditation criteria. Additionally, we remind users that fulfilling the criteria mentioned in this application is merely helping the documentation of patient safety part, and not all accreditation process. The users should notice that accreditation include not only documentation, but also process / standard operational procedure in daily routines. This application does not replace any of the process in accreditation, and therefore, the final score does not reflect the accreditation status (basic/intermediate/major/complete). In order to understand the function of this application, users could read the manual book or tutorial video as provided. 

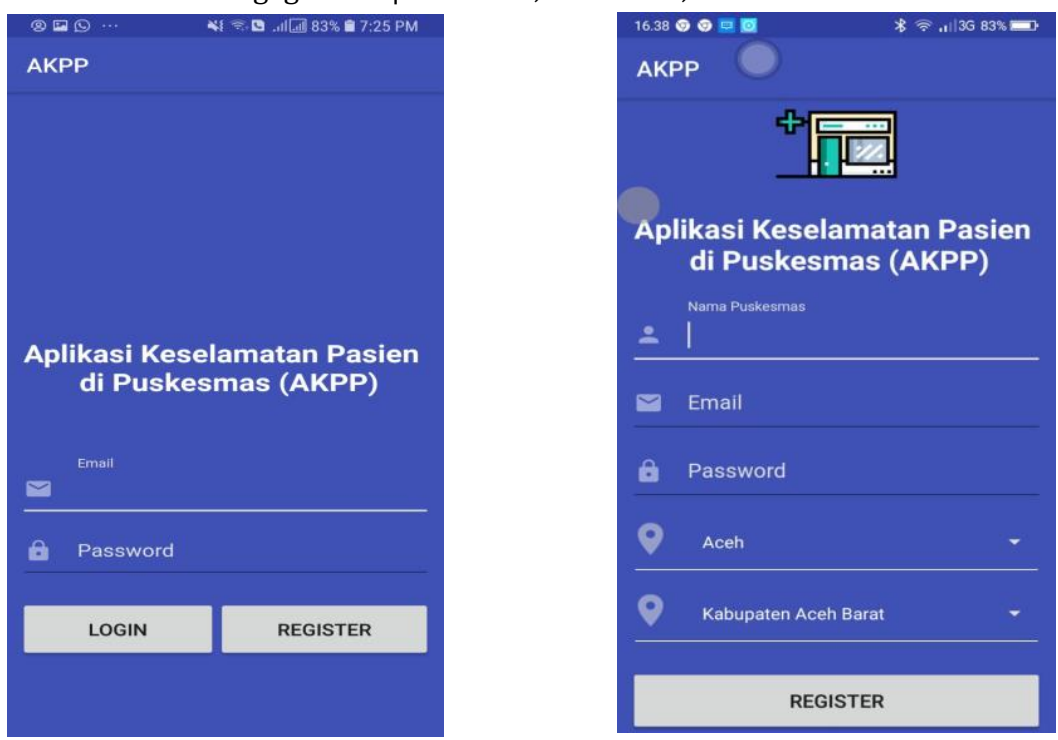

Fg. 3 Login and Registration Page

Source: Author (2018)

At the moment, this registration is merely applied for Puskesmas. Everyone could register for this application; however, it is better for one Puskesmas to have only one account. Every staff who involve in patient safety in Puskesmas could access the same account. One Puskesmas should have only one login access to enter the application. This is also to ensure the data is accessible to the authorized Puskesmas staff. The input data by users can only be accessed by the assigned user and it is assured that others could not access the data.

The content of this application consists of 12 sub-chapters. When the user entered the application, he/she would see the all sub-chapters as seen in Chapter 9. We did not change the numbering since it would be easier for the user to understand the content. User could click on the sub-chapter, and then he/she would find the elements for assessment in each sub-chapter.

In each element for assessment, we provide users with the definition of the element and slot to upload necessary documents. User could upload documents by entering the website address. They would receive the QR scan code and capture the code as a proof to the application that they had uploaded the document. The uploaded documents should be in PDF format. This is also one of the weakness of this application. Documents in other formats, e.g. word, excel, could not be uploaded. 
Levina Chandra Khoe, Ajeng Pramastuty, Boy Subirosa Sabarguna, Herqutanto | ASEAN Journal of Community

Engagement | Volume 3, Number 2, 2019
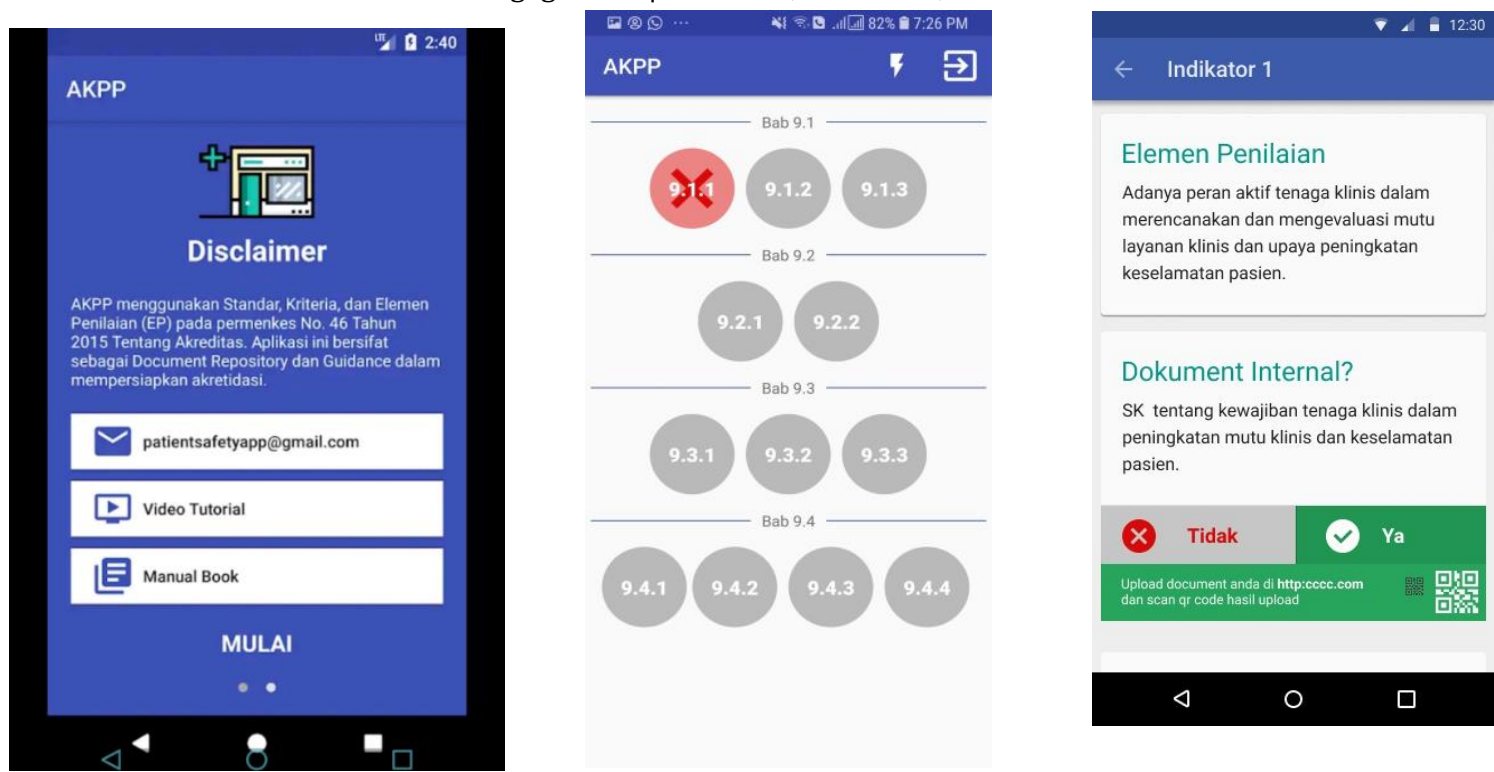

Fg. 4 Indicator Page

Source: Author (2018)

In the sub-chapter page, the user could see the red cross sign if he/she had not completed the assessment element and green sign if they had fulfilled the criteria. The red and green sign would enable the users to monitor their own progress. There would be a final score with maximum score 580 if they fulfilled all the indicators. They would receive zero if they did not upload any documents, and ten for each indicator if they could submit all the necessary documents. The final score is used as a basis for decision support system, in which user will receive suggestions/recommendations for their missing parts.

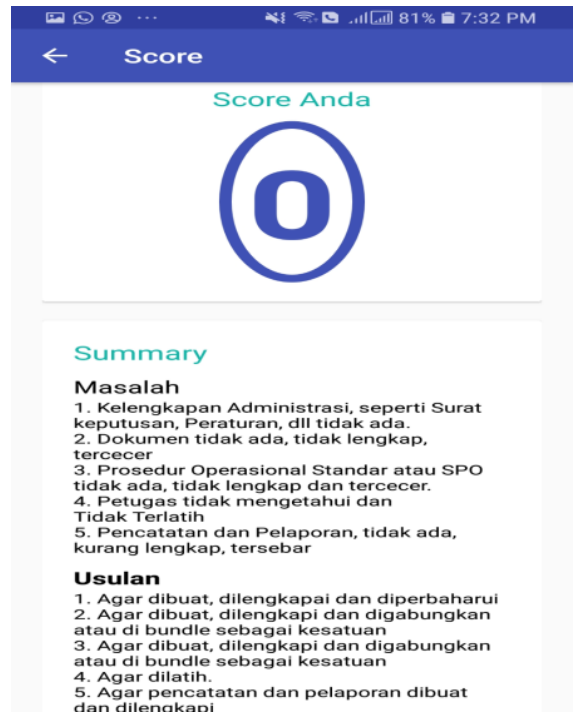

Fg. 5 Score system

Source: Author (2018) 
Levina Chandra Khoe, Ajeng Pramastuty, Boy Subirosa Sabarguna, Herqutanto | ASEAN Journal of Community Engagement | Volume 3, Number 2, 2019

\subsection{Evaluation result from IT persons}

We asked three IT persons to download the application and test each of the function from the front page until summary page. The IT persons filled in the survey in Likert scale from 0 (worst) to 4 (excellent performance) to assess the general function of application and the system flow. In terms of general function, 75\% (3 out of 4) gave mark of 3 (good), and one person gave mark of 4 (excellent). While for the system flow and content, half respondents (50\%) gave good mark, $25 \%$ gave excellent mark, and the other $25 \%$ gave less (2). In addition, we also asked their input to improve the application. The IT persons suggested to add more option on uploading documents. For instance, there should be an option to upload documents from smartphone or using photos. Having single option, i.e. using website and QR scan, would takes more time and not user friendly.

\subsection{Evaluation result from users}

In order to understand the feasibility of this application, we disseminated questionnaires for 23 Puskesmas staff, every staff represents one Puskesmas. We distributed the questionnaires through link of Google form. We did promotion and socialization to these Puskesmas regarding the use of this mobile application. We used Likert scale to ask respondent's satisfaction regarding the function of mobile application. Zero means totally disagree and five means totally agree.

Table 2. Result of Respondent's Evaluation

\begin{tabular}{lll}
\hline No & Question & Mean score \\
\hline 1 & Front display of application & 3,80 \\
2 & Understanding of manual book & 3,85 \\
3 & Easy to register to the application & 4,15 \\
4 & Easy to understand the definition of each & 3,85 \\
& indicator & \\
5 & Easy to upload document & 3,30 \\
6 & This application could help to prepare & 3,80
\end{tabular}




\begin{tabular}{lll}
\hline No & Question & Mean score \\
\hline 7 & This application could improve Puskesmas & 3,70 \\
& performance \\
8 & This application corresponds with 3,60 \\
& Puskesmas needs \\
9 & This application could encourage us to be 3,40 \\
& independent in working on Puskesmas \\
& program \\
10 & This application could improve local 3,75 \\
& potential to achieve accreditation \\
11 & We could use this application independently & 3,30 \\
& (without help from UI) & \\
12 & Satisfaction level for application & \\
13 & UI team provides clear information about & 4,00 \\
& this application
\end{tabular}

Source: Author (2018)

All respondents were eager to disseminate information about this application towards their colleagues. However, there were some difficulties in using this application, for instance: 1) difficulty in uploading document because they need to use computer; 2) option for canceling to upload document; 3) unavailability in apple store. Respondents also suggested for additional function to directly upload documents from smartphone; adding other components of accreditation; ability to check the validity of documents; adding documents for references; and adding place to keep files about near miss events, incidents, etc. Despite the weakness of this application, all respondents agreed that the application would be helpful to monitor the progress of completing necessary documents for accreditation.

This is the first application that specifically accommodates Puskesmas needs for accreditation in patient safety. It is also tested among Puskesmas staff, who are the target users of this application. By using this application, Puskesmas staff could monitor their performance on patient safety program independently. However, we are also aware that there are some flaws in this application. First, this application merely focuses on Chapter 
Levina Chandra Khoe, Ajeng Pramastuty, Boy Subirosa Sabarguna, Herqutanto | ASEAN Journal of Community Engagement | Volume 3, Number 2, 2019

nine, and has not included other chapters. While some documents necessary in Chapter nine may link to other chapters as well. Second, the current application has no function to check whether users have uploaded the correct documents according to its indicators or not. Users could save the necessary documents, upload and download documents; however, they may not understand the validity of the documents. Third, as this is a pilot version, currently it is available only in Google Play Store. We would expand the use of this application to bigger target users and display it in Apple Store as well.

\section{Conclusion}

Patient safety mobile application in Puskesmas is an easy-to-use smartphone-based application to accomplish accreditation based on the Regulation of Minister of Health No 46 Year 2015. Puskesmas staff could easily upload documents and monitor their activities through this mobile application.

Recognizing the needs of Puskesmas and the benefits of this application, we would recommend the use of this application to wider community. More Puskesmas to be reached, including those outside Jakarta. As responded by participants, the respondents are willing to recommend this application to their colleagues, therefore, more Puskesmas can use this application to monitor their activities and achieve better patient safety system.

\section{Acknowledgements}

This study was made possible by a grant from Universitas Indonesia. Application is publicly accessible from Google Play Store. We thank Rumah Coding to help in developing mobile application. We are also grateful for Directorate of Primary Care, Ministry of Health, and Health Sub-district Office in North Jakarta for their valuable input. And last, we are thankful for Department of Community Medicine and Health District DKI Jakarta to provide opportunity for us to promote this application for Puskesmas staff in DKI Jakarta.

\section{Author Contribution}

All authors conceived of the presented idea, developed the theory and performed the computations. Levina Chandra Khoe developed the first draft. Levina Chandra Khoe and 
Levina Chandra Khoe, Ajeng Pramastuty, Boy Subirosa Sabarguna, Herqutanto | ASEAN Journal of Community Engagement | Volume 3, Number 2, 2019

and Ajeng Pramastuty did the analysis. Boy Subirosa Sabarguna and Herqutanto supervised the findings of this work. All authors discussed the results and contributed to the final manuscript.

\section{References}

Boulos, M. N., Brewer, A. C., Karimkhani, C., Buller, D. B., \& Dellavalle, R. P. (2014). Mobile medical and health apps: state of the art, concerns, regulatory control and certification. Online Journal of Public Health Informatics, 5(3), e229. https://doi.org/10.5210/ojphi.v5i3.4814

BPJS Kesehatan. (2017, June). Laporan Pengelolaan Program dan Laporan Keuangan Jaminan Sosial Kesehatan. Retrieved from

https://bpjs-

kesehatan.go.id/bpjs/dmdocuments/b39df9ae7a30a5c7d4bd0f54d763b447.pdf

Braun, B.I., Owens, L.K., Bartman, B.A., Berkeley, L., Wineman, N., \& Daly, C.A. (2008). Quality-related activities in federally supported health centers: do they differ by organizational characteristics? J Ambulatory Care Manage, 31, 303-318. https://dx.doi.org/10.5455\%2Faim.2013.21.176-179

Buetow, S.A., \& Wellingham, J. (2003). Accreditation of general practices: challenges and lessons. Qual Saf Health Care, 12, 129-135. https://doi.org/10.1136/qhc.12.2.129

Darzi, A. (2008, June). High quality care for all: NHS Next Stage Review Final Report. Department of Health. Retrieved from https://assets.publishing.service.gov.uk/government/uploads/system/uploads/att achment_data/file/228836/7432.pdf

DKI Jakarta local government (n. d.). Daftar Puskesmas [List of Puskesmas]. Retrieved from: https://surveilans-dinkesdki.net/puskesmas.php

Ekawati, F. M., Claramita, M., Hort, K., Furler, J., Licquirsh, S., \& Gunn, J. (2017). Patients' experience of using primary care services in the context of Indonesian universal health coverage reforms. Asia Pac Fam Med, 16(4), 1-10. https://apfmj.biomedcentral.com/articles/10.1186/s12930-017-0034-6

El-Jardali, F., Hemadeh, R., Jaafar, M., Sagherian, L., El-Skaff, R., Mdeihly, R., \& Ataya, N. (2014). The impact of accreditation of primary healthcare centers: Successes, challenges and policy implications as perceived by healthcare providers and 
Levina Chandra Khoe, Ajeng Pramastuty, Boy Subirosa Sabarguna, Herqutanto | ASEAN Journal of Community Engagement | Volume 3, Number 2, 2019

directors in Lebanon. BMC Health Services Research, 14(1), 1-10. https://doi.org/10.1186/1472-6963-14-86

Institute of Medicine US Committee on Quality of Health Care in America. (2000). Errors in health care: a leading cause of death and injury. In L. Kohn, J. Corrigan, \& M. Donaldson (Eds.), To Err is Human. Washington DC: National Academies Press.

Jaafaripooyan, E., Agrizzi, D., \& Akbari-Haghighi, F. (2011). Healthcare accreditation systems: further perspectives on performance measures. International Journal for Quality in Health Care, 23(6), 645-656. https://doi.org/10.1093/intqhc/mzr063

Kapur, N. (2015). Accreditation of services would improve patient safety. BMJ, 351, h4420. Lawati, M. H. A., Dennis, S., Short, S. D., \& Abdulhadi, N. N. (2018). Patient safety and safety culture in primary health care: a systematic review. BMC Fam Pract, 19, 104.

Lewis, T. L., \& Wyatt, J. C. (2014). MHealth and mobile medical apps: A framework to assess risk and promote safer use. J Med Internet Res, 16(9), e210. https://doi.org/10.2196/jmir.3133

Lu, C., Hu, Y., Xie, J., Fu, Q., Leigh, I., Governor, S., \& Wang, G. (2018). The use of mobile health applications to improve patient experience: cross-sectional study in Chinese public hospitals. JMIR Mhealth Uhealth, 6(5), e126. https://doi.org/10.2196/mhealth.9145

Marchon, S.G., \& Mendes, W. V. Jr. (2014). Patient safety in primary health care: a systematic review. Cad Saude Publica, 30, 1815-1835. https://doi.org/10.1590/0102-311x00114113

Ministry of Health. (2017). Laporan akuntabilitas kinerja instansi pemerintah [report of accountability performance of government institution]. Retrieved from: http://yankes.kemkes.go.id/app/lakip2/downloads/2017/KP/ditjen/lakip_ditjen_2 017.pdf

Ministry of Health. (2018). Data dan informasi - profil kesehatan Indonesia. [Data and information - health profile of Indonesia]. Retrieved from https://www.depkes.go.id/resources/download/pusdatin/profil-kesehatanindonesia/Data-dan-Informasi_Profil-Kesehatan-Indonesia-2018.pdf

Ozdalga, E., Ozdalga, A., \& Ahuja, N. (2012). The smartphone in medicine: a review of current and potential use among physicians and students. J Med Internet Res, 14(5), e128. https://doi.org/10.2196/jmir.1994 
Levina Chandra Khoe, Ajeng Pramastuty, Boy Subirosa Sabarguna, Herqutanto | ASEAN Journal of Community Engagement | Volume 3, Number 2, 2019

Paccioni, A., Sicotte, C., \& Champagne, F. (2008). Accreditation: a cultural control strategy. Int Health Care Qual Assur, 21, 146-158. https://doi.org/10.1108/09526860810859012

Putri, N. E. (2014). Efektivitas Penerapan Jaminan Kesehatan Nasional melalui BPJS dalam Pelayanan Kesehatan Masyarakat Miskin di Kota Padang. Tingkap, 10(2), 175-189. http://ejournal.unp.ac.id/index.php/tingkap/article/view/4421

Peraturan Menteri Kesehatan 2015 No 46. Akreditasi Puskesmas, Klinik Pratama, Tempat Praktik Mandiri Dokter, dan Tempat Praktik Mandiri Dokter Gigi. [Accreditation of Community Health Centre, Private Clinic, Independent Practice for Doctors and Dentists].

Peraturan Menteri Kesehatan 2017 No 11. Keselamatan pasien. [Patient safety]

Qiang, C. Z., Yamamichi, M., Hausman, V., \& Altman, D. (2011). Mobile Applications for the Health Sector. World Bank Documents \& Reports - Abstracts, 1-61.

Santosa, H., \& Malek, N. M. (2011). penilaian kualitas pelayanan pusat kesehatan masyarakat di wilayah Sumatera Utara, Indonesia. [Quality assessment on health service in community health centre in North Sumatra, Indonesia]. Jurnal Manajemen Pelayanan Kesehatan, 14(01), 49-54.

Shaw, C. D., Groene, O., Botje, D., Sunol, R., Kutryba, B., \& Klazinga, N. (2014). The effect of certification and accreditation on quality management in 4 clinical services in 73 European hospitals. Int J Qual Health Care, 26, 100-107. https://doi.org/10.1093/intqhc/mzu023

Statista. (2019, February 19). Number of smartphone users in Indonesia from 2011 to 2022 (in millions). Retrieved from https://www.statista.com/statistics/266729/smartphone-users-in-indonesia/

Ventola, C. L. (2014). Mobile devices and apps for health care professionals: uses $\begin{array}{lllll}\text { and benefits. } & P & \& & T, & 39(5),\end{array}$ https://www.ncbi.nlm.nih.gov/pmc/articles/PMC4029126/

World Health Organization. (2003). Quality and accreditation in health care services. Retrieved from http://www.who.int/hrh/documents/en/quality_accreditation.pdf World Health Organization. (2017). Patient Safety: Making health care safer. Geneva: World Health Organization. Retrieved from 
Levina Chandra Khoe, Ajeng Pramastuty, Boy Subirosa Sabarguna, Herqutanto | ASEAN Journal of Community

Engagement | Volume 3, Number 2, 2019

http://apps.who.int/iris/bitstream/handle/10665/255507/WHO-HIS-SDS-

2017.11-eng.pdf?sequence=1 